\title{
Covid-19: Lack of capacity led to halting of community testing in March, admits deputy chief medical officer
}

\section{Gareth lacobucci}

The BMJ

The UK's decision to stop community testing and contact tracing for covid-19 in early March was partly driven by a lack of testing capacity, England's deputy chief medical officer, Jenny Harries, has admitted.

On 12 March, as cases of the virus soared, the government announced that it would stop all community testing for covid-19 and focus instead on testing people in hospitals and protecting health workers as it moved from the "contain" phase to the "delay" phase.

The government is now promising to restart community testing and contact tracing to help suppress the number of cases when lockdown measures are eased, but many public health experts believe that it should not have stopped community testing in March. ${ }^{1}$

Harries has defended the government's approach, saying in March that community testing was "not an appropriate intervention" at that stage of the pandemic given the widespread prevalence. In a session at the Commons Health Select Committee on 5 May she was asked directly whether she still felt that way.

"The issue here is what capacity do we have to undertake testing and where should that be prioritised," she said. "If we had unlimited capacity and the ongoing support beyond that then we would perhaps choose a slightly different approach.”
The UK government has now expanded testing capacity, but Harries said that this alone was not sufficient to fight the virus.

She said, "We refer to Germany a lot. But just on the testing alone, the number of tests in Germany is broadly similar to the number of tests carried out in Italy, so testing per se doesn't have a direct causative link, it is the follow-on activity-the contact tracing."

Also appearing at the committee hearing was the UK's chief scientific adviser, Patrick Vallance, who also raised the issue of testing capacity when he was asked what the UK could have done differently in terms of strategy.

"Probably in the early phases, if we'd managed to ramp up testing capacity quicker it would have been beneficial," he said. "For all sorts of reasons that didn't happen. It is clear you need lots of testing for this. But it's just part of the system you need to get right. The entire system needs to work properly, and you need to have that link to contact tracing [and] isolation."

lacobucci G. Covid-19: UK pledges to reintroduce contact tracing to fight virus. $B M J$ 2020;369:m1591. 10.1136/bmj.m1591 32317295

Published by the BMJ Publishing Group Limited. For permission to use (where not already granted under a licence) please go to http://group.bmj.com/group/rights-licensing/ permissions 